\title{
Newly discovered breeding sites of Olrog's Gull Larus atlanticus in Argentina
}

\author{
PABLO YORIO, GABRIEL PUNTA, DANIEL RABANO \\ FABIAN RABUFFETTI, GONZALO HERRERA, JOSE SARAVIA and \\ PABLO FRIEDRICH
}

\section{Summary}

Olrog's Gull Larus atlanticus is a threatened and endemic species to the Argentine Atlantic coast. We present information on seven new colonies and update information on known colonies obtained during 1992-1995. Five of the new colonies were in southern Buenos Aires and two in southern Chubut. Total population size, including already known colonies, was estimated at 2,30o breeding pairs. All colonies were located on islands and islets and were associated with breeding Kelp Gulls Larus dominicanus. The new colonies extend the known breeding range of Olrog's Gull to the north and increase the overall known population size. However, the aerial survey also showed that two colonies found in 1990 no longer exist. Almost $40 \%$ of the total breeding population breed within the Bahía Blanca estuary, an area currently subject to intense human pressure. Olrog's Gull is still a species with restricted distribution and low population size. We suggest conservation actions needed to adequately protect this threatened species.

\section{Introduction}

Olrog's Gull Larus atlanticus, for which further research and protection are needed (Escalante 1984, Collar et al. 1992), is endemic to the Argentine Atlantic coast. To develop adequate conservation and management strategies, knowledge is needed on its breeding distribution and total population size. Previous information indicates that Olrog's Gull bred in two areas of the Argentine coast: Bahía Anegada, southern Buenos Aires, and Caleta Malaspina, Chubut, with a total population size of 1,200 breeding pairs distributed in five colonies (Yorio and Harris 1992). However, Yorio and Harris (1992) suggested that additional colonies could exist in southern Buenos Aires, as some sectors of the coast with apparently suitable breeding habitat had not been adequately surveyed. We present information on new breeding colonies and update information on known colonies.

\section{Methods}

We surveyed sections of the coastline of the province of Chubut by boat during seabird research conducted in December 1992 by the Dirección General de 
Intereses Marítimos y Pesca Continental, Chubut, and during seabird population evaluations conducted during the breeding seasons of 1993 to 1995 within the Patagonian Coastal Zone Management Plan (GEF/PNUD). We determined the size of the Olrog's Gull colonies by full nest counts during the late incubation period. We revisited the colonies at Bahía Melo and Caleta Malaspina during the years following their discovery to monitor colony status.

On 11 November 1995 we surveyed the coast and islands from Bahía Blanca to Bahía San Blas, Buenos Aires, by plane. We used a Cessna 182, flying at an altitude of $100-300 \mathrm{~m}$ with observers at both sides of the plane. We photographed each colony encountered using $35-\mathrm{mm}$ cameras with $80-200$ and $300-\mathrm{mm}$ lenses, and estimated their size by counts from the photos. We considered as a breeding pair any incubating gull or pair associated with a nest. The population size for each location is an average of at least three counts made by two of us on each colony photograph.

\section{Results}

We located seven new breeding colonies, five of which were in southern Buenos Aires and two in southern Chubut (Table 1). Total population size, including already known colonies, was estimated at 2,300 breeding pairs. All colonies were located on islands and islets and were associated with breeding Kelp Gulls Larus dominicanus. The aerial survey showed that colonies at Isla Brightman and Isla Gama found in 1990 (Yorio and Harris 1992) no longer exist.

Four of the colonies in southern Buenos Aires were at the north-east sector of Isla Trinidad $\left(39^{\circ} 12^{\prime} S 61^{\circ} 52^{\prime} \mathrm{W}\right)$. These colonies were on four different islets within an area of approximately $2 \mathrm{~km}^{2}$, and varied in size from about 65 to 440 nests (Table 1.) Isla Trinidad is included within the "Isla Embudo, Bermeja y Trinidad Reserve". The fifth colony in southern Buenos Aires was located on an islet between Islote Colina de los Riachos and Isla Morro de Indio, only a few $\mathrm{km}$ north of the northern limit of the "Bahía San Blas Reserve".

The new colonies in southern Chubut were in the northern sector of the Golfo San Jorge. The first was at Isla Laguna, a small vegetated island within the Bahía Melo which is connected to the mainland at low tide. The second was at Isla Felipe, a small island located approximately $2 \mathrm{~km}$ from the mainland. Both colonies were smaller than those in southern Buenos Aires (Table 1).

\section{Discussion}

Our surveys extended the known breeding range of Olrog's Gull to the north and increased the overall known population size. Colony sizes obtained are minimum estimates, as some pairs could have lost their eggs before or laid after we made our survey. The two colonies which no longer exist were in areas which are currently subject to human activities. Peninsula Verde and Caleta Brightman are highly modified due to development, and Isla Gama has farming and ranching activities, several buildings and an airstrip for small planes (Gimenez Dixon 1986). Olrog's Gulls breeding in these disturbed sites may have moved to other locations. More thorough surveys of the area in southern Buenos Aires are needed, as our study showed the existence of islets and banks 
Table 1. Location and size ( \pm SD) of Olrog's Gull breeding colonies for the 1992 to 1995 breeding seasons (census date in parenthesis). For comparative purposes, we also present the information from the 1990 breeding season (Yorio and Harris 1992)

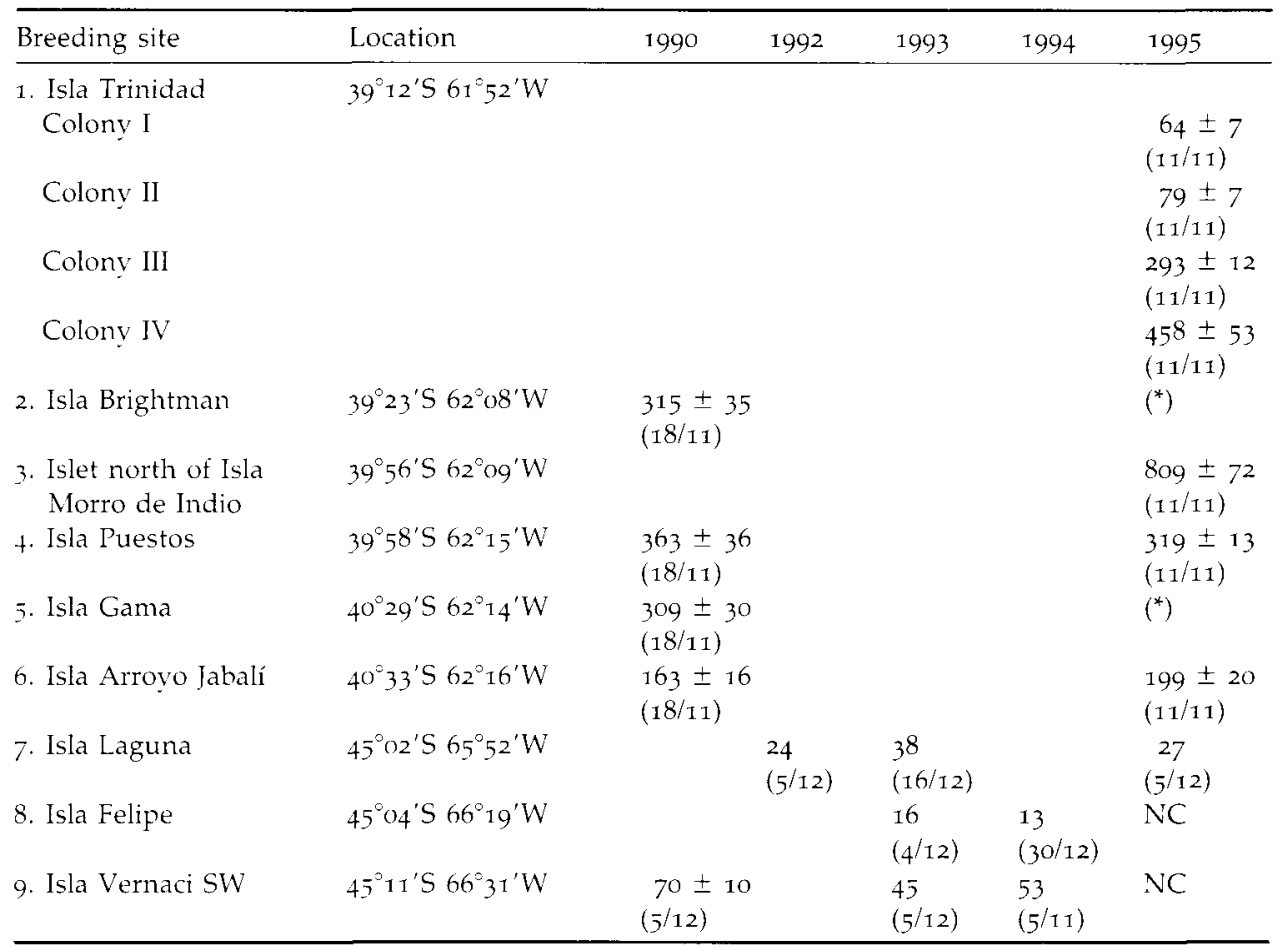

$\mathrm{NC}$, breeding birds present during this season but no census was conducted.

$\left.{ }^{*}\right)$ Colonies reported in 1990 were not found during this season.

with apparently adequate nesting habitat that are not recorded in regional or local charts.

The colonies within the Bahía Blanca estuary represent $38 \%$ of the total known breeding population of Olrog's Gull. This area is subject to intense human pressure from urban development, industry, agriculture, recreation and fishing. Increased pollution resulting from these activities is also threatening the coastal environment.

The four new colonies in the Bahía Blanca estuary are within the "Isla Embudo, Bermeja y Trinidad Reserve". However, protection of the islands is not adequately enforced and surrounding intertidal mudflats used as foraging grounds by Olrog's Gulls are not included within the reserve. The colony located between Islote Colina de los Riachos and Isla Morro de Indio is a few kilometres outside the northern boundary of the "Bahía San Blas Reserve". The limits of this reserve should be enlarged to include the northern islands, islets and banks. The absence of the breeding colony at Isla Gama also suggests that the management guidelines for the "Bahía San Blas Reserve" need revising. Colonies along the Chubut coast have no protection at all, though they are within areas subject to coastal development, including macroalgae exploitation 
and guano extraction. These activities do not appear to threaten the breeding of Olrog's Gull, although indirect effects of disturbance have not been evaluated.

Our wor's shows a wider breeding range and larger population size than was thought to exist but Olrog's Gull must still be consivered a species with restricted distribution and low population size. Future work on this threatened species should include (i) a more thorough survey of the islands and banks between "Isla Embudo, Bermeja y Trinidad Reserve" and Península Verde to confirm current breeding distribution, (ii) the monitoring of existing colonies due to the observed short-term changes in colony location and population estimates, (iii) the extension of existing reserves to include the Islote Colina de los Riachos colony in the case of "Bahía San Blas Reserve" and the surrounding intertidal mudflats in the case of the "Isla Embudo, Bermeja and Trinidad Reserve", and (iv) the designation of protected areas in southern Chubut, in order to include at least part of the southern population of Olrog's Gull.

\section{Acknowledgements}

We thank the Patagonian Coastal Zone Management Plan, GEF/PNUD, implemented by Fundación Patagonia Natural and Wildlife Conservation Society, for the support to conduct the surveys in southern Buenos Aires and part of the field work in Chubut. We also thank the Dirección General de Intereses Marítimos y Pesca Continental, Chubut, for institutional support to conduct surveys in Chubut, and W. Melo (IADO), Soriano S.A., and M. José for logistical support. Thanks to F. Quintana for helpful comments on the manuscript.

\section{References}

Collar, N., Gonzaga, L., Krabbe, N., Madroño Nieto, A. G., Naranjo, L. G., Parker, T. A. and Wege, D. (1992) Threatened birds of the Americas: the ICBP Red Data Book. Cambridge, UK: International Council for Bird Preservation.

Escalante, R. (1984) Problemas en la conservación de dos poblaciones de láridos sobre la costa Atlántica de Sud América [Larus (belcheri) atlanticus y Sterna maxima]. Reì. Mus. Cs. Nat. "B. Rivadavia". Zool. XIII (14).

Gimenez Dixon, M. (1986) Informe de la evaluación efectuada con relación a la creación de una reserva faunística en la zona de Bahía San Blas (Pdo. Patagones). Ministerio de Asuntos Agrarios. Pcia. de Bs. As.

Yorio, P. and Harris, G. (1992) Actualización de la distribución reproductiva, estado poblacional y de conservación de la gaviota de Olrog (Larus atlanticus). El Hornero 13: 200-202.

\section{PABLO YORIO}

Fundación Patagonia Natural and Wildife Conservation Society, M. Zar 760, 9120, Puerto Madryn, Chubut, Argentina.

\section{GABRIEL PUNTA, JOSE SARAVIA}

Dirección General de Intereses Maritimos y Pesca Continental and Universidad Nacional de la Patagonia San Juan Bosco, 9 de Julio y J.A. Roca, 9103, Razuson, Chubut, Argentina. 
DANIEL RABANO, FABIAN RABUFFETTI, PABLO FRIEDRICH

Universidad Nacional del Sur, Perú 670, 8000, Bahía Blanca, Buenos Aires, Argentina.

GONZALO HERRERA

Universidad Nacional de la Patagonia San Juan Bosco, Belgrano 504, 910o Trelew, Chubut, Argentina. 